\title{
Landscape Integrity Eclipses Local Effects of Floral Resource Availability on Bumble Bee (Bombus Spp.) Abundance in a Water-Limited Island Ecosystem
}

Andrew Simon ( $\square$ adfsimon@imerss.org )

University of Victoria https://orcid.org/0000-0002-5358-8974

Brian M. Starzomski

University of Victoria

\section{Research Article}

Keywords: bumble bee, community ecology, landscape integrity, habitat diversity, seasonal drought, disturbance, water-limited ecosystem

Posted Date: December 29th, 2021

DOI: https://doi.org/10.21203/rs.3.rs-1128511/v1

License: (c) (1) This work is licensed under a Creative Commons Attribution 4.0 International License. Read Full License 


\section{Abstract}

Context

Habitat loss threatens to exacerbate climate change impacts on pollinator communities, particularly in Mediterranean-type ecosystems where late season floral resource availability is limited by seasonal drought. While gardens have been found to supplement floral resources in water-limited urban landscapes, less is known about the role of natural habitat diversity in sustaining late season floral resources in more intact landscapes.

Objectives

We investigated the importance of habitat integrity and diversity for bumble bees in a water-limited ecosystem, observing bumble bee community response to seasonal drought across gradients of disturbance and soil moisture.

Methods

We applied hierarchical models to estimate the effects of local site conditions versus landscape scale estimates of matrix habitat on bumble bee abundance. Floral resources, soil moisture, and other environmental variables were sampled along randomly distributed belt transects. Geospatial estimates of matrix habitat were derived from terrestrial ecosystem data. Bumble bees were sampled with blue vane traps.

Results

In the late season we found that modified wet areas supported more floral resources and bumble bee workers as compared to dry semi-natural environments. Wetlands also supported more late season floral resources and bumble bee workers, though the latter effect was not significant.

Despite higher levels of late season floral resources in modified wet environments, modified matrix habitat was negatively associated, and natural matrix positively associated, with workers in June and late-flying queens in July and August. We also detected differences in bumble bee community composition in disturbed versus undisturbed environments.

\section{Conclusions}

Though wet modified habitats sustained the highest levels of late season floral resource availability and worker abundances in our study, bumble bee diversity and abundance were limited primarily by the availability of natural matrix habitat at the landscape scale. The conservation of natural habitat integrity and diversity can help support critical nesting and foraging habitat, and should be prioritized in efforts to foster the resilience of pollinator communities.

\section{Introduction}


Climate change has been implicated in the worldwide decline of bumble bees (Bombus Latreille, 1802) as temperature and precipitation begin to exceed the historically observed tolerances of species, and some species ranges recede to higher latitudes and elevations (Biella et al. 2017; Guzman et al. 2021; Kerr et al. 2015; Soroye et al. 2020). Numerous other anthropogenic stressors, including habitat fragmentation and industrial agriculture, also threaten to exacerbate these effects (Sanchez-Bayo and Goka 2014; Shackelford et al. 2018; Szabo et al. 2012). In Mediterranean-type ecosystems, climate change portends increasingly extreme winter precipitation events, and more intense, prolonged seasonal drought-factors likely to broadly affect species ranges and interspecific dynamics (Dale et al. 2001; Hansen et al. 2001; Salathé et al. 2008; Seager et al., 2019; Spies et al. 2010). These changes may have numerous direct and indirect consequences for bumble bees and the plant communities upon which they depend (Hoiss et al. 2015; Minckley et al. 2013; Simon et al. 2021; Straka and Starzomski 2014; Thomson 2016).

Increasing drought may cause reductions in floral resources supporting pollinators, resulting in a lower proportion of flowers containing nectar, fewer flowers per inflorescence, and reduced floral richness and abundance (Phillips et al. 2018; Simon et al. 2021). Drought has also been found to advance flowering phenology among annual herbaceous plants (König et al. 2017), and to cause stress or reduced productivity among perennial shrubs (Pérez-Camacho et al. 2012). In turn, overall species diversity in plant-pollinator communities has been found to decline under conditions of drought stress (Hoiss et al. 2015). These effects could potentially benefit generalist pollinators such as bumble bees, or, conversely, promote specialists with narrower foraging requirements (Minckley et al. 2013; Thomson 2016). Drought has moreover been found to exacerbate effects of interspecific competition between honey bees (Apis mellifera Linnaeus, 1758) and bumble bees, reducing the foraging and reproductive success of native bumble bee populations (Thomson 2016).

Bumble bees are central place foragers limited by the availability of both nesting and foraging habitat. Compositionally diverse landscapes offering a mosaic of herbaceous and forested habitats are known to promote the availability of foraging and nesting resources, and in turn, a greater abundance of bumble bees (Jha et al. 2013; Kennedy et al. 2013; McFrederick and LeBuhn 2006; Wray and Elle 2015). From the bumble bee perspective, beneficial habitat diversity might include semi-natural woodlands and wetlands, as well as gardens, railway embankments, and utility rights-of-way (Hill and Bartromeus 2016; Morón et al. 2014; Vickruck et al. 2019). Indeed, researchers have suggested that urban gardens and agricultural systems supporting a diversity of mass-flowering plants in the late season may be more important than "unimproved" semi-natural habitats in sustaining bumble bees, particularly in drought-prone environments (Heard et al. 2007; McFrederick and Lebuhn 2006; Wray and Elle 2015).

Research has tended to contrast agricultural and urban habitats with only one alternative semi-natural habitat type-generally in the context of highly fragmented landscapes (e.g., Heard et al. 2007; Hill and Bartromeus 2016; Moroń et al. 2014; Wray and Elle 2015). Landscape heterogeneity, however, gives rise to a gradient of environments that may provide important foraging habitat over the course of the growing season. While gardens provide important late season foraging habitat in urban landscapes (Heard et al. 2007; McFrederick and Lebuhn 2006; Wray and Elle 2015), natural habitats such as wetlands may also support late season floral resources and thereby serve a similar function in more ecologically intact environments. Certain 
bumble bee species may also be favoured by semi-natural habitats, while others exhibit greater affinities for disturbed areas. On the northwest coast of North America, for example, Bombus vosnesenskii Radoszkowski, 1862 (yellow-headed bumble bee) has expanded its range in recent decades, becoming a dominant species in urban environments, where other species, such as Bombus occidentalis Greene, 1858 (western bumble bee) and Bombus sitkensis Nylander, 1848 (Sitka bumble bee), have been observed to decline (Colla and Ratti 2010; McFrederick and LeBuhn 2006; Simon, unpublished data).

We investigated the importance of habitat integrity and diversity for bumble bees in a water-limited ecosystem by observing flowering plant and bumble bee community response to seasonal drought across gradients of disturbance and soil moisture. We predicted that dry semi-natural habitats such as woodlands would host fewer floral resources and, in turn, fewer bumble bee workers than other habitat types during the dry late season. Conversely, we predicted that modified wet habitats such as gardens, and wet semi-natural habitats such as wetlands, would support greater floral resources, and, in turn, a greater abundance of workers in the late season. Disturbance was predicted to promote late season floral resource availability among exotic plant species, with bumble bee workers expected to persist longer in disturbed environments both wet and dry. We also tested whether surrounding natural and modified matrix habitat influenced bumble bee abundance at the site level, analyzing the response of each species and caste. Finally, we tested whether different habitat types favoured certain species, with Bombus vosnesenskii expected to be more prominent in disturbed environments.

\section{Methods}

Study area

Galiano Island lies in the rain shadow of the Olympic Mountains and the Vancouver Island Ranges, in southern coastal British Columbia, Canada. This region is defined by its temperate Mediterranean-type climate, with mild, wet winters and warm, dry summers (Klassen et al. 2015). The combined effects of low precipitation, warm temperatures, and high sunshine hours result in an annual moisture deficit during summer months, which varies to some extent depending on precipitation (Moore et al. 2010). These conditions are expected to become more extreme under projected climate change scenarios: increases in winter precipitation and the intensity and duration of seasonal drought are likely in this system (Salathé et al., 2008; Seager et al., 2019; Spies et al., 2010).

Galiano Island is relatively intact ecologically, with about $24 \%$ of its land base conserved in protected areas and a high percentage of forest cover, hosting vegetation communities typical of the Coastal Douglas-fir Biogeoclimatic Zone (Nuszdorfer et al., 1991). Although the island has historically been subject to extensive industrial forestry practices, only $\sim 11 \%$ of the landscape has been converted for present day human use (Madrone 2008). This largely forested study area thus presents a contrast to the fragmented environments previously studied by pollinator researchers in water-limited ecosystems (e.g., McFederick and LeBuhn 2005; Wray and Elle 2015).

Sampling 
This study was based on a $2 \times 2$ factorial study design contrasting four conditions of disturbance and soil moisture availability: 1) dry semi-natural environments (woodland and associated rock outcrop communities); 2) wet semi-natural environments (wetlands); 3) dry modified environments (disturbed upland areas such as clear-cuts and hydro-line corridors); and, 4) wet modified environments (gardens, orchards and fields). Sites were stratified based on available terrestrial ecosystem mapping data (Madrone, 2008), with 6 sites selected per condition (for a total of 24 sites). Limitations in existing site conditions and the logistics of site access resulted in an imbalance in the study design, with 4 sites representing the wet seminatural condition versus 8 sites representing the dry seminatural condition (and 6 sites representing the other two conditions).

Terrestrial ecosystem mapping data were used to obtain estimates of land cover falling within a $500 \mathrm{~m}$ buffer around each site, orienting around polygon centroids, including natural, modified, and forested matrix habitat (Fig. 1). Natural matrix habitat included coniferous and deciduous forest cover at various structural stages, as well as wetlands, woodlands, meadows, and rock outcrops. Modified matrix included rural, agricultural and developed land cover. Sites ranged in size from 0.21 to 6.3ha (Supplementary Information). While grouped site conditions circumscribed similar habitat types based on common soil moisture regimes, disturbance conditions were diverse, including forestry, fire, landscaping, and other anthropogenic effects. Commonalities between site conditions (henceforth habitat types) are reflected in the similarity of vegetation communities, as shown in ordination plots (Supplementary Information). Additional environmental data were collected along transects at the site level, including estimates of canopy cover, slope, moss cover, coarse woody debris, and bare soil-variables known to correlate with bumble bee nesting habitat (Potts et al. 2005; Wray and Elle 2015).

To sample floral resource availability (FRA), we stratified habitat types and randomly distributed 6-8 (2× 15 $\mathrm{m}$ ) belt transects throughout each site, using balanced acceptance sampling methods to ensure a random yet spatially balanced distribution of transects (van Dam-Bates et al., 2018). The number of transects was scaled roughly in proportion to the size of each site, with the aim of capturing variability in floral resource availability across the landscape. Floral resource availability was quantified as counts of flowering shoots, recorded for each plant species at 1-m intervals, with each interval surveyed comprising a $1 \times 2 \mathrm{~m}$ area spanning both sides of the transect line. Soil moisture was recorded at 5-m intervals as volumetric water content (\%VWC) using a Field Scout Time-Domain Reflectometry probe. Sampling was conducted on a monthly basis from April through August 2018, resulting in five samples per site, with each sample period covering 13 days.

To sample bumble bees, three blue vane traps (Stephen and Rao 2005) were placed at roughly equidistant intervals across each site. Traps were positioned to ensure their visibility given surrounding vegetation and landscape features, and to minimize public interference. Bumble bees captured by blue vane traps were pooled into one sample per site, resulting in $24 \times 5$ (120) samples divided into the four habitat types. Blue vane traps were vandalized in a dry semi-natural site in May, resulting in the loss of one sample $(n=120$ $1=119$ ). Bumble bees were identified following Williams et al. (2014).

Modelling 
Statistical analyses were implemented in R Version 3.6.0 (R Core Team 2019). Linear mixed effects models (LMMs) were fitted incorporating log-transformed soil volumetric water content (logVWC) as a response to contrasting habitat types (fixed effects), with transects nested within sites (random effects), to estimate differences in soil moisture between habitat types. To estimate differences in floral resource availability (FRA), we fit negative binomial generalized linear mixed effects models (GLMMs) incorporating counts of flowering shoots as a response to contrasting habitat types (fixed effects) and transects nested within sites (random effects) for discrete sample periods. We also modeled FRA as a seasonal pattern, by fitting a GLMM incorporating time (julian days) as a quadratic term to estimate overall differences in FRA across site conditions. While time emerged as a significant term in these models, the quadratic term did not adequately describe the observed seasonal patterns in FRA, resulting in a poor fit. Hence, our analyses have focused on discrete sample periods instead. Negative binomial generalized linear mixed effects models were also fitted to model mean bumble bee abundance (counts) as a function of habitat type and sample periods (fixed effects), with a random intercept term corresponding to site. Other environmental variables incorporated as predictors included proportions of natural and modified matrix, forest cover, slope and moss cover.

Significant terms were evaluated based on model summaries, and top models selected based on AIC scores (see below).

We estimated differences in the total count of bumble bees sampled between habitat types for each sample period separately. Because our focus was on whether certain habitat types supported prolonged foraging under conditions of drought stress, we concentrated primarily on bumble bee worker abundance as a proxy for bumble bee foraging activity, though differences were also considered among drones and queensespecially late-flying queens, whose presence in the environment may be considered a proxy for the reproductive success of colonies. We fitted GLMs to estimate differences in the abundance of bumble bees within isolated sample periods, as temporal autocorrelation was not problematic in these analyses. We also modelled the abundance of each species as a response to habitats and other environmental variables, both across sample periods (GLMMs) and within sample periods (GLMs). Linear mixed effects models were implemented using the R package 'nlme' (Pinheiro et al. 2021); GLMs were implemented using the R package 'MASS' (Venables and Ripley 2002); and GLMMs implemented using 'Ime4', and 'glmmTMB' in cases where zero-inflation proved problematic (Bates et al. 2015, Brooks et al. 2017). The best models were selected based on AIC test scores, assuming $\triangle \mathrm{AIC}$ of 2.0 as a threshold for model improvement (Burnham and Anderson 2002). Model effects are reported as Incidence Rate Ratios (IRR), and as marginal $R^{2}$ values (variance explained by fixed effects) for GLMMs. For GLMs, pseudo (Nagelkerke) $R^{2}$ values are presented for significant terms. Marginal effects were calculated using 'sjPlot' (Lüdecke 2018).

\section{Results}

Onset of seasonal drought

Soil moisture declined with the onset of seasonal drought across all habitats (Fig. 2). Dry semi-natural and dry modified sites declined to $1.5 \pm 1.5 \%$ volumetric water content (VWC) by June, and had similarly low soil moisture conditions throughout the rest of the growing season. Wet semi-natural sites sustained relatively high soil moisture, declining from $20.6 \pm 1.1 \%$ VWC in June to $10.6 \pm 1.2 \%$ VWC in August. Wet modified sites 
were comparatively dry yet significantly wetter than dry sites from June (10.9 $\pm 1.5 \% \mathrm{VWC})$ until August (4.6 $\pm 1.5 \%$ VWC).

The foraging landscape

Plant community phenology varied significantly across habitats, resulting in distinct peaks and declines in floral resource availability (FRA) over the course of the growing season (Fig. 3). In dry semi-natural and dry modified habitats, FRA peaked early (in May), supporting significantly more FRA than wet semi-natural habitats from April through May. In wet semi-natural and wet modified habitats, FRA peaked later (in June). Both wet and disturbed conditions sustained FRA later into the season, with wet semi-natural, wet modified and dry modified habitats supporting significantly more FRA than dry semi-natural habitats from June through August. By August, significantly higher FRA was found in wet modified, wet semi-natural, and dry modified habitats versus dry semi-natural environments, in rank order of abundance, with wet modified environments supporting nearly twenty times more FRA than dry semi-natural environments $\left(\right.$ IRR $\left._{\text {WET.M. }}=17.70_{\text {DRY.N. }}, p<0.001\right)$.

Disturbance was also a critical factor promoting floral resource availability among exotic plants (Fig. 4). The highest levels of floral resources were found in dry modified environments in May and June, driven by the invasive Cytisus scoparius (L.) Link (Scotch broom). With decreasing soil moisture, FRA became increasingly concentrated among exotics, with significantly higher FRA found among exotic versus native plants overall from June through August. By August, exotic species pervaded most environments, with FRA among native plants diminishing to less than a quarter of that among exotics $\left(\operatorname{IRR}_{\text {EXO }}=0.23_{\text {NAT. }}, p<0.001\right)$. In dry seminatural habitats, FRA was exclusively found among exotic plants. Wet semi-natural habitats, by contrast, sustained significantly higher levels of FRA among native plants throughout the growing season $\left(I_{\mathrm{RAT}}=2.53_{\mathrm{EXO} \cdot,} p=0.05\right)$.

Bumble bee abundance

There was no significant difference in bumble bee worker abundance among habitats from April through May as colonies were getting established. By June, however, dry modified (IRR DRY.M. $\left.=5.58_{\text {WET.N. }}, p<0.001\right)$, wetmodified (IRR WET.M. $\left.=3.33_{\text {WET.N. }} p=0.001\right)$, and dry semi-natural habitats $\left(\operatorname{IRR}_{\text {DRY.N. }}=3.32_{\text {WET.N. }}, p=0.001\right)$ hosted significantly more bumble bee workers than wet semi-natural habitats (Fig. 5). In July, bumble bee worker abundance declined in both dry modified and dry semi-natural habitats. Meanwhile worker abundance peaked in wet semi-natural and modified environments. However, no significant differences in worker abundance was detected between habitats in July. Workers declined dramatically across all habitats by August (Fig. 6). During August, wet modified habitats supported significantly more workers than dry seminatural habitats $\left(\operatorname{IRR}_{\text {WET.M. }}=3.07_{\text {DRY.N. }}, p=0.008\right)$, which supported the fewest workers. Wet semi-natural and dry modified habitats also supported more workers than dry semi-natural habitats in August, though these differences were not significant (Fig. 6).

Environmental predictors of bumble bees across the landscape 
We modeled the response of bumble bees across all habitats and sample periods, as well as the response of discrete species and castes, as a function of several geospatial parameters and environmental variables known to be associated with foraging and nesting resources (Table 1). Floral resource availability (FRA) was the only significant predictor of bumble bee abundance across all habitat types (Table 2). Although FRA was not a significant predictor of workers across all sample periods, FRA was a significant predictor of workers in May. Additionally, FRA was a significant predictor of late-flying queens (in July and August). Natural matrix habitat was a significant predictor of workers in June, and a significant predictor of late-flying queens.

Conversely, modified matrix habitat was a significant negative predictor of workers in June, and a significant negative predictor of late-flying queens. The inclusion of matrix habitat as a term in models explained a much greater proportion of variance in bumble bee abundances versus other local environmental parameters, including FRA (Table 2). No other terms were statistically important or otherwise improved model AIC scores in these analyses.

Table 1

Environmental variability across habitats. Mean and standard deviation are reported for: floral resource availability (counts of flowering shoots per $15 \times 2 \mathrm{~m}$ transect, averaged per site); matrix habitat represented by natural versus modified land cover (ha) within a $500 \mathrm{~m}$ radius of sites; and site environmental parameters: slope, canopy cover, moss cover and coarse woody debris cover (\%)

\begin{tabular}{|llllllll|}
\hline Habitat & FRA & $\begin{array}{l}\text { Natural } \\
\text { matrix }\end{array}$ & $\begin{array}{l}\text { Modified } \\
\text { matrix }\end{array}$ & Slope & $\begin{array}{l}\text { Canopy } \\
\text { cover }\end{array}$ & $\begin{array}{l}\text { Moss } \\
\text { cover }\end{array}$ & $\begin{array}{l}\text { CWD } \\
\text { cover }\end{array}$ \\
\hline Dry modified & $\begin{array}{l}46 \\
\pm 40\end{array}$ & $39.2 \pm 7.9$ & $38.2 \pm 8.6$ & $18 \pm 7$ & $19 \pm 14$ & $15 \pm 6$ & $9 \pm 4$ \\
\hline $\begin{array}{l}\text { Dry semi- } \\
\text { natural }\end{array}$ & 26 & $41.7 \pm 20.1$ & $14.4 \pm 10.9$ & $\begin{array}{l}51 \\
\pm 31\end{array}$ & $55 \pm 19$ & $23 \pm 11$ & $10 \pm 5$ \\
\hline Wet modified & 39 & $43.8 \pm 12.5$ & $34.0 \pm 12.7$ & $8 \pm 3$ & $18 \pm 12$ & $4 \pm 4$ & $2 \pm 4$ \\
\hline $\begin{array}{l}\text { Wet semi- } \\
\text { natural }\end{array}$ & 41 & $63.4 \pm 4.2$ & $14.9 \pm 12.7$ & $9 \pm 4$ & $36 \pm 12$ & $8 \pm 10$ & $13 \pm 3$ \\
\hline
\end{tabular}


Table 2

Environmental predictors of bumble bee abundance, summarized for top models. Model summaries include Incidence Rate Ratios, 95\% confidence intervals, and random effects variance for predictors of bumble bee abundance generally, as well as for a set of castes and species for which model terms proved significant (or otherwise improved model AIC scores)

$\begin{array}{llllllllll}\begin{array}{l}\text { Model / } \\ \text { Response }\end{array} & \text { Predictor } & \text { IRR } & \mathrm{Cl} & p & \sigma^{2} & \tau_{00 \text { Site.ID }} & \text { ICC } & n & R^{2}\end{array}$




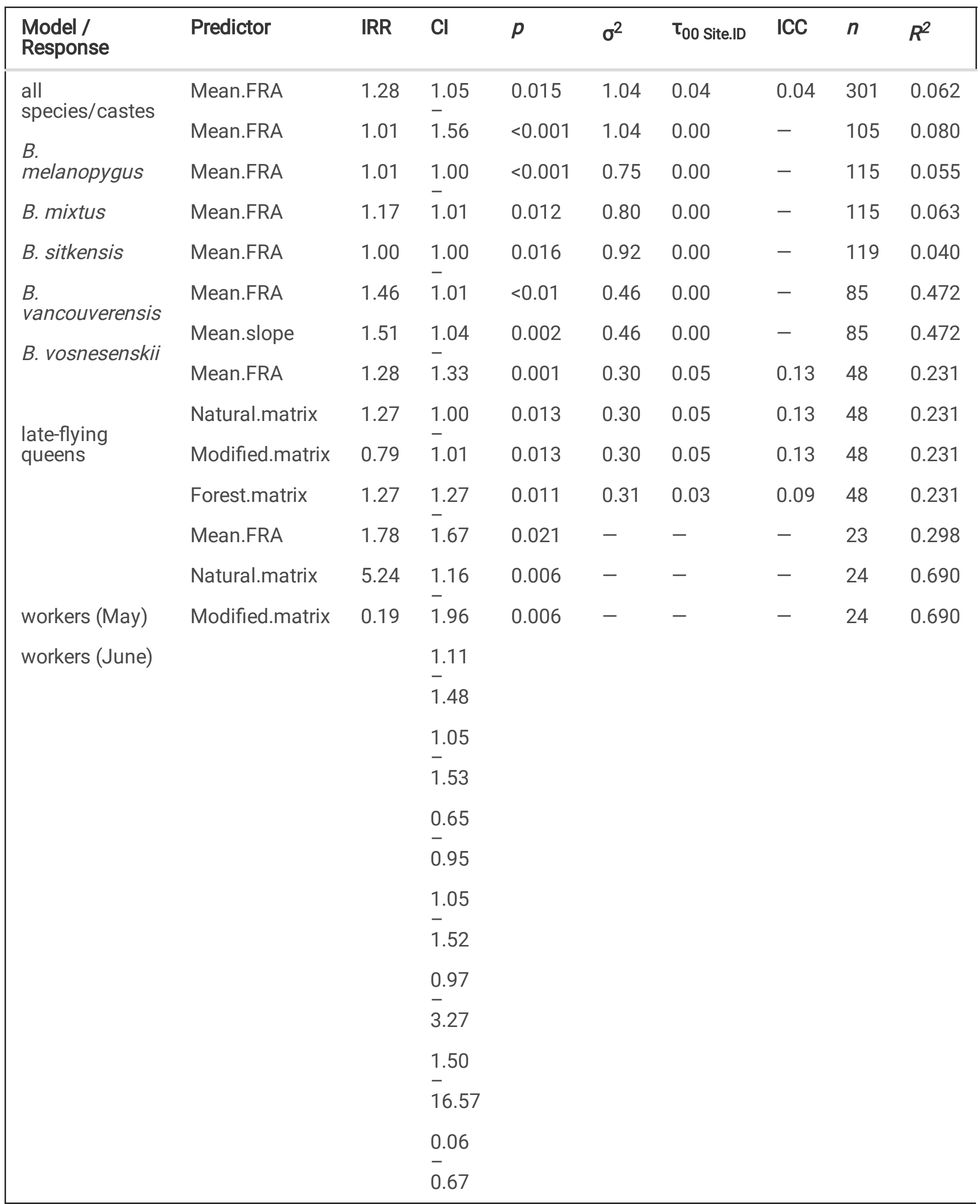

Species-specific responses 
Six bumble bee species (Bombus flavifrons Cresson, 1863; Bombus melanopygus Nylander, 1848; Bombus mixtus Cresson, 1878; Bombus sitkensis Nylander, 1848; Bombus vancouverensis Cresson, 1878; and $B$. vosnesenskii Radoszkowski, 1862) were captured in blue vane traps during this study, all of which were present throughout all four habitat types. Floral resource availability was a significant predictor of all bumble bee species abundance except Bombus flavifrons.

Bombus sitkensis was a moderately abundant bumble bee species, sampled with $\sim 60 \%$ the frequency of the most abundant species, $B$. vancouverensis, across all habitats $\left(\mathrm{IRR}_{\mathrm{B} . \mathrm{SIT}}=0.59_{\mathrm{B} . \mathrm{VAN} .}, p<0.001\right)$. Bombus sitkensis was significantly more abundant in wet semi-natural habitats versus dry modified habitats $\left(I_{\text {WET.N. }}=1.74_{\text {DRY.M., }} p=0.022\right)$ where this species was least abundant. Mean FRA was also a significant term predicting the abundance of $B$. sitkensis (Table 2).

Bombus vosnesenskii was the least abundant bumble bee species sampled in this study-less than a third as abundant as $B$. vancouverensis ( $\left.\operatorname{IRR}_{\mathrm{B} . V O S}=0.28_{\mathrm{B} . \mathrm{VAN} .}, p<0.001\right)$. This species occurred with greatest abundance in dry modified habitats and lowest abundance in wet semi-natural habitats $\left(\mathrm{IRR}_{\mathrm{DRY} . \mathrm{M}}=3.51_{\text {WET.N. }}\right.$. $p<0.001)$. Wet modified habitats also hosted significantly more $B$. vosnesenskii individuals than wet seminatural habitats (IRR WET.M. $\left._{\text {. }}=2.49_{\text {WET.N. }} p=0.046\right)$. Additionally, mean slope and FRA were significant predictors in the top model explaining Bombus vosnesenskils abundance in the environment (Table 2).

\section{Discussion}

Many bumble bee species are in decline due to habitat loss and diminished floral resources resulting from agricultural intensification (Goulson et al. 2008; Szabo et al. 2012; Sanchez-Bayo and Goka 2014). Climatic stressors including drought have also been found to cause declines and range shifts in certain species, though the overall effects of global climate change on bumble bee communities remain unclear (Biella et al. 2017; Hoiss et al. 2015; Guzman et al. 2021; Kerr et al. 2015; Soroye et al. 2020; Thomson 2016). Our study highlights the role of habitat diversity and integrity in buffering against these stressors in a Mediterranean type ecosystem. Compositionally rich landscapes hosting floral resources throughout both the early and late season are known to support greater bumble bee numbers and nesting density, and are vital to ensure the intergenerational survival of bumble bees (Carvell et al. 2017; Knight et al. 2009; Williams et al. 2012). As predicted, we found that disturbance and soil moisture were critical factors influencing seasonal fluctuations in floral resources and bumble bee abundance across the foraging landscape. By August, wet modified habitats such as gardens hosted significantly more floral resources and bumble bee workers than dry seminatural habitats. Wetlands also hosted nearly twice as many workers than dry habitats in August, though this difference was not significant. Habitat diversity thus played an important role promoting the seasonal availability of floral resources in this water-limited ecosystem. Ultimately, however, habitat integrity proved most important for bumble bees: natural matrix habitat was the strongest predictor of workers in June and late-flying queens.

Our results accord, in part, with previous findings emphasizing the role of modified environments such as gardens in promoting late season foraging habitat for bumble bees in water-limited ecosystems (Heard et al. 2007; Hill and Bartromeus 2016; McFrederick and Lebuhn 2006; Wray and Elle 2015). However, we also found 
evidence that semi-natural habitat diversity-and natural matrix habitat more broadly-correlated with greater abundances of bumble bees on the landscape in some cases. Worker abundance in dry semi-natural habitats was comparable to abundances found in dry disturbed habitats throughout the growing season, despite significantly higher levels of late season floral resources in the latter environments. Furthermore, in dry seminatural habitats, late season declines in worker abundance were not as severe as seen within more impacted ecosystems such as the fragmented oak savannahs of the nearby Saanich Peninsula on Vancouver Island. In this system, Wray and Elle (2015) found pollinator diversity and abundance to decline sharply in dry woodlands from June through August, tracking closely with decreasing floral resources-except where surrounding urban matrix habitat supplemented diminishing floral resources in these environments. We found a different pattern: high numbers of bumble bee workers were sustained in dry semi-natural habitats through June and July, despite a dramatic decline in floral resources. Moreover, modified matrix habitat was correlated with decreased abundance, and natural matrix habitat with increased abundance, of workers in June, and late-flying (reproductive) queens in July and August. Bumble bees thus appeared to be resilient to local declines in floral resources, with workers (in June) and late-flying queens occurring in greater numbers in sites surrounded by natural matrix habitat, independent of variation in local site conditions. This pattern suggests that, while gardens may play an important role supplementing late season floral resources in fragmented urban and agricultural landscapes, the availability of natural matrix habitat may be more limiting for bumble bees in more intact landscapes.

Bumble bees are known to forage at great distances, depending on resources available in the environment (Darvill et al. 2004; Hagen et al. 2011; Heinrich 1979; Jha and Kremen 2013; Knight et al. 2005). Documented foraging ranges vary significantly-from $1.5 \mathrm{~km}$ (Osborne et al. 2008) to as far as $11.6 \mathrm{~km}$ (Rao and Strange 2012). Given these ranges, colonies may be sustained in resource-poor patches providing sufficient resources are available in surrounding matrix habitat. Thus, while previous research has identified urban centres as critical sources of late season floral resources in water-limited ecosystems (McFrederick and LeBuhn 2006; Wray and Elle 2015), the results of this study suggest the availability of natural matrix habitat may place more critical limits on bumble bee productivity and reproduction at the landscape scale. Dramatic contrasts in landscape conditions between the study areas previously investigated and those of Galiano Island support this argument. Despite its history of industrial forestry, Galiano Island's ecosystems remain relatively intact, with $\sim 11 \%$ of the landscape converted for present day human use (Madrone 2008). In contrast, the urban and agricultural landscapes investigated in previous studies are much more fragmented (McFrederick and LeBuhn 2006; Wray and Elle 2015) -e.g., less than $5 \%$ of the Saanich Peninsula remains in its natural state (MacDougall et al. 2004; Shackelford et al. 2019). More research is required to clarify the relative importance of foraging versus nesting habitat, and how it limits the abundance and survivability of bumble bees in waterlimited ecosystems, especially where landscapes have not yet been converted for human use.

Wetlands as refuges for bumble bees during late season drought?

While recent research has found wetlands to be important for pollinators in agricultural landscapes (Vickruck et al. 2019), our study did not support the hypothesis that wetlands provide important foraging habitat for bumble bees in this water-limited ecosystem. Through the early season, floral resource availability (FRA) remained significantly lower in wetlands than other habitats, and wetlands were host to correspondingly low 
numbers of workers. Bumble bee nesting density is known to be directly related to floral abundance, especially early season FRA (Knight et al. 2009; Williams et al. 2012), which may have resulted in decreased abundance of bumble bee workers in these habitats. Yet it is also possible that wetlands are generally less habitable to ground-dwelling bumble bees than drier, upland habitats. Wet conditions have been observed to hamper bumble bee colony development (Harder 1986), and pollinator nesting is also known to be positively associated with moderately sloped upland habitats (Potts et al. 2005; Wray and Elle 2015). Wetlands may therefore be avoided by nesting queens, resulting in a lower density of colonies in these environments. In wetlands, worker abundance peaked in July-one month after FRA reached its peak-which suggests a lag in the productivity of local colonies. This pattern is also apparent across other habitat types, with worker abundance climaxing in the months following peak flowering events.

Wetlands nevertheless supported greater floral resource availability than dry semi-natural habitats in the late season. Moreover, in contrast to all other habitats, where exotic plants became increasingly prevalent, wetland FRA was found chiefly among native plants. These findings indicate that natural habitat diversity may be especially important in intact landscapes, as the diversity emergent across soil moisture gradients may be necessary to support the availability of early and late season floral resources in native plant communities. Indeed, in the absence of major anthropogenic disturbance events, soil moisture gradients were likely crucial in shaping plant-pollinator interactions across the foraging landscapes of the past-particularly for insects having annual colony cycles such as bumble bees, which depend on the availability of both early and late season floral resources (Rundlöf et al. 2014; Williams et al. 2012). Since the mid 1800s, however, disturbances associated with European colonization have altered these ecosystems, with changing predatorprey dynamics resulting in increased deer browsing pressures, and land conversion resulting in natural habitat loss and the introduction of a high diversity of exotic plants (Martin et al. 2011; Marx et al. 2016). Exotic plants in disturbed environments now contribute a significant proportion of floral resources in this system (Marx et al. 2016; Simon et al. 2021). These disturbed conditions may favour certain bumble bee species over others, contributing to modern day shifts in plant-pollinator community dynamics (Cole et al. 2019; Fraser et al. 2012; McFrederick and LeBuhn 2006).

Bumble bee community dynamics

This study revealed patterns in the distribution of Bombus vosnesenskii and B. sitkensis that are interesting to note in light of research suggesting competitive interactions between these species (McFrederick and LeBuhn 2006). We found Bombus vosnesenskii to be most abundant in dry upland environments, where $B$. sitkensis was least abundant, whereas Bombus sitkensis was most abundant in wetlands, where $B$. vosnesenskii was least abundant. In British Columbia, Bombus vosnesenskii has undergone significant and rapid range expansion since 2000, demonstrating an impressive capacity for colonization (Fraser et al. 2012). This species is now dominant in urban environments throughout coastal western North America, where its abundance is correlated with reduced bumble bee species richness, resulting in the apparent exclusion of $B$. sitkensis (Cole et al. 2019; McFrederick and LeBuhn 2006). Because both species are ground nesters, researchers speculate that this negative relationship may be due to competition for nesting habitat (McFrederick and LeBuhn 2006). To the extent that Bombus vosnesenksii demonstrated a preference for disturbed upland environs on Galiano Island, it may be that $B$. sitkensis has found a haven in lowland 
habitats where it is less subject to competition with $B$. vosnesenskii. On the other hand, the effect of competitive exclusion could be confounded by opposing habitat preferences. Indeed, while competitive exclusion may be a factor contributing to the decline of $B$. sitkensis in southern coastal portions of its range, this is not the case at higher elevations and latitudes where its range does not overlap with $B$. vosnesenskii (Hatfield et al. 2014). The results of this study suggest that the niche of these species may also be partitioned based on nesting and foraging preferences in relation to habitat diversity at smaller scales.

Despite its capacity for colonization, Bombus vosnesenskii was the least abundant bumble bee sampled on Galiano Island in 2018. Its preference for disturbed environments may be limiting its establishment on this relatively forested island. In California, researchers have noted that this species is not as abundant in less fragmented environments, suggesting a threshold of urbanization that must be crossed to bring about this species' dominance (McFrederick and LeBuhn 2006). The sparse occurrence of Bombus vosnesenskii on Galiano Island-a rural island that remains relatively intact ecologically-supports this hypothesis. However, this pattern may also be due to a recent colonization event, as this species has only expanded its range over the last couple decades (Fraser et al. 2012) and was not previously known from Galiano Island's historical record (Simon et al., in prep.).

\section{Conclusions}

Habitat loss and fragmentation are major threats to terrestrial biodiversity worldwide (Rogan and Lacher 2018). For bumble bees, as for other species, conservation depends on protecting intact ecosystems and ensuring quality matrix habitat is available to buffer against the stress of climate change and habitat destruction (Franklin and Lindenmayer 2009). Our study corroborates previous findings emphasizing the importance of compositionally rich landscapes for bumble bees (Carvell et al. 2017; Knight et al. 2009; Williams et al. 2012), providing insight into these effects in the context of a Mediterranean-type ecosystem that exhibits distinct peaks and declines in floral resources due to seasonal drought. In this system, natural habitat diversity across the soil moisture gradient, from woodlands to wetlands, supported floral resources throughout the growing season. While human modified settings such as orchards and gardens supported greater floral resources and worker abundance in the late season, modified matrix habitat had a stronger negative effect overall on the occurrence of bumble bees. Our results thus underline an important lesson for pollinator conservation in the face of climate change and increasing habitat destruction. Across fragmented urban and agricultural landscapes, restoration interventions may be required to promote the foraging habitat necessary to foster diverse pollinator communities. However, such measures are of secondary importance to conservation in the context of more intact natural ecosystems. Where possible, the conservation of natural habitat integrity and diversity-across the spectrum of dry to wet habitat types-can help support critical nesting and foraging habitat, and should be prioritized in efforts to foster the resilience of pollinators on the landscape.

\section{Declarations}

\section{Acknowledgments}


We are grateful to the BC Parks Living Lab program, the lan McTaggart Cowan Professorship in the School of Environmental Studies at the University of Victoria, and the Natural Sciences and Engineering Research Council of Canada for funding this research. Pascale Archibald, Lincoln Best, Sarah Johnson, Daniel Kirkpatrick, Kevin Toomer, and Marika van Reeuwyk supported field work and aided with the processing and identification of bumble bees. Trevor Lantz provided valuable feedback on early drafts, and Nancy Shackelford and Allan Roberts provided support with statistical analyses. Claudia Copley and Joel Gibson supported this work in research collections at the Royal British Columbia Museum. We also thank the following organizations who provided access to the sites necessary to conduct this research: BC Parks, Crystal Mountain Society, Islands Trust Conservancy, Galiano Club, Galiano Conservancy Association, Galiano Island Parks and Recreation Commission, Garry Oak Meadow Preservation Society, and Tapovan Sri Chinmoy Peace Park. Finally, we thank the many Galiano Island community members who permitted sampling on private land, and who otherwise facilitated this work.

\section{Statements and Declarations}

This research was funded by the BC Parks Living Labs (Ministry of Environment and Climate Change Strategy Agreement \# TP19JHQ014) and the Natural Sciences and Engineering Research Council of Canada (RGPIN 2017 04476).

The authors have no relevant financial or non-financial interests to disclose.

\section{Compliance with Ethical Standards}

This research was conducted by permit issued under the authority of the Park Act by the Ministry of Environment and Climate Change Strategy (Park Use Permit No 109244). Voucher specimens have been deposited at the Royal British Columbia Museum [XXXX in process].

\section{Data Accessibility:}

All data and scripts necessary to reproduce this research are available on the Dryad Data Repository: [XXXXX Insert Link]

\section{Author contributions:}

Conceptualization: Andrew Simon, Brian Starzomski; Methodology: Andrew Simon; Formal analysis and investigation: Andrew Simon; Writing - original draft preparation: Andrew Simon; Writing - review and editing: Andrew Simon, Brian Starzomski; Funding acquisition: Brian Starzomski; Resources: Andrew Simon, Brian Starzomski; Supervision: Brian Starzomski.

\section{References}

1. Bates D, Maechler M, Bolker B, Walker S (2015) Fitting linear mixed-effects models using Ime4. J Stat Softw 67(1):1-48. https://www.doi.org/abc/10.18637/jss.v067.i01 
2. Biella P, Bogliani G, Cornalba M, Manino A, Neumayer J, Porporato M, Rasmont P et al (2017) Distribution patterns of the cold adapted bumblebee Bombus alpinus in the Alps and hints of an uphill shift (Insecta: Hymenoptera: Apidae). J Insect Conserv 21(2):357-366. https://doi.org/10.1007/s10841-017-9983-1

3. Brooks ME, Kristensen K, van Benthem KJ, Magnusson A, Berg CW, Nielsen A, Skaug HJ et al (2017) glmmTMB balances speed and flexibility among packages for zero-inflated generalized linear mixed modeling. R J 9(2):378-400. https://doi.org/10.32614/RJ-2017-066

4. Burnham KP, Anderson DR (2002) Model Selection and Inference: A Practical Information-Theoretical Approach, 2nd edn. Springer-Verlag, New York

5. Carvell C, Bourke AFG, Dreier S, Freeman SN, Hulmes S, Jordan WC, Redhead JW et al (2017) Bumblebee family lineage survival is enhanced in high-quality landscapes. Nature 543(7646):547-549.

https://doi.org/10.1038/nature21709

6. Cole JS, Siegel RB, Loffland HL, Tingley MW, Elsey EA, Johnson M (2019) Explaining the birds and the bees: deriving habitat restoration targets from multi-species occupancy models. Ecosphere 10(4):e02718. https://doi.org/10.1002/ecs2.2718

7. Colla SR, Ratti CM (2010) Evidence for the decline of the Western Bumble Bee (Bombus occidentalis Greene) in British Columbia. Pan-Pac Entomol 86(2):32-34. https://doi.org/10.3956/2009-22.1

8. Dale VH, Joyce LA, McNulty S, Neilson RP, Ayres MP, Flannigan MD, Hanson PJ et al (2001) Climate change and forest disturbances. Bioscience 51(9):723-734. https://doi.org/10.1641/00063568(2001)051[0723:CCAFD]2.0.CO;2

9. Darvill B, Knight ME, Goulson D (2004) Use of genetic markers to quantify bumblebee foraging range and nest density. Oikos 107(3):471-478. https://doi.org/10.1111/j.0030-1299.2004.13510.x

10. Franklin JF, Lindenmayer DB (2009) Importance of matrix habitats in maintaining biological diversity. PNAS 106:349-350. https://doi.org/10.1073/pnas.0812016105

11. Fraser D, Copley C, Elle E, Cannings R (2012) Changes in the status and distribution of the Yellow-faced Bumble Bee. J Entomol Soc B C 109:31-37

12. Goulson D, Lye GC, Darvill B (2008) Decline and conservation of bumble bees. Annu Rev Entomol 53:191-208. https://doi.org/10.1146/annurev.ento.53.103106.093454

13. Guzman LM, Johnson SA, Mooers AO, M'Gonigle LK (2021) Using historical data to estimate bumble bee occurrence: variable trends across species provide little support for community-level declines. Biol Cons 257:109141. https://doi.org/10.1016/j.biocon.2021.109141

14. Hagen M, Wikelski M, Kissling WD (2011) Space use of bumblebees (Bombus spp.) revealed by radiotracking. PLoS ONE 6(5):e19997. https://doi.org/10.1371/journal.pone.0019997

15. Hansen AJ, Neilson RP, Dale VH, Flather CH, Iverson LR, Currie DJ, Shafer S et al (2001) Global change in forests: responses of species, communities, and biomes. Bioscience 51(9):765-779. https://doi.org/10.1641/0006-3568(2001)051[0765:GCIFRO]2.0.C0;2

16. Harder LD (1986) Influences on the density and dispersion of bumble bee nests (Hymenoptera: Apidae). Ecography 9(2):99-103. https://doi.org/10.1111/j.1600-0587.1986.tb01196.x

17. Hatfield R, Colla S, Jepsen S, Richardson L, Thorp R, Foltz S (2014) IUCN Assessments for North American Bombus spp. for the North American IUCN Bumble Bee Specialist Group. The Xerces Society 
for Invertebrate Conservation. https://xerces.org/sites/default/files/publications/14-065.pdf. Accessed 30 November 2021

18. Heard MS, Carvell C, Carreck NL, Rothery P, Osborne JL, Bourke AFG (2007) Landscape context not patch size determines bumble-bee density on flower mixtures sown for agri-environment schemes. Biol Lett 3(6):638-641. https://doi.org/10.1098/rsbl.2007.0425

19. Heinrich B (1979) Bumblebee economics. Harvard University Press, Cambridge

20. Hill B, Bartomeus I (2016) The potential of electricity transmission corridors in forested areas as bumblebee habitat. R Soc Open Sci 3(11):1-12. https://doi.org/10.1098/rsos.160525

21. Hoiss B, Krauss J, Steffan-Dewenter I (2015) Interactive effects of elevation, species richness and extreme climatic events on plant-pollinator networks. Glob Change Biol 21(11):4086-4097. https://doi.org/10.1111/gcb.12968

22. Jha S, Kremen C (2013) Bumble bee foraging in response to landscape heterogeneity. PNAS 8:555-558

23. Jha S, Stefanovich L, Kremen C (2013) Bumble bee pollen use and preference across spatial scales in human-altered landscapes. Ecol Entomol 38(6):570-579. https://doi.org/10.1111/een.12056

24. Kennedy CM, Lonsdorf E, Neel MC, Williams NM, Ricketts TH, Winfree R, Bommarco R et al (2013) A global quantitative synthesis of local and landscape effects on wild bee pollinators in agroecosystems. Ecol Lett 16(5):584-599. https://doi.org/10.1111/ele.12082

25. Kerr J, Jeremy T, Pindar A, Galpern P, Packer L, Potts SG, Roberts SM, Rasmont P et al (2015) Climate change impacts on bumblebees converge across continents. Science 349(6244):177-180. https://doi.org/10.1126/science.aaa7031

26. Klassen H, Saunders SC, Kranabetter K, MacKinnon A, Griesbauer H, Fitzpatrick O (2015) Establishment of an interdisciplinary project to evaluate ecological implications of climate change in dry south coast forest ecosystems. (Technical Report 086). Ministry of Forests, Lands and Natural Resource Operations, Nanaimo

27. König P, Tautenhahn S, Cornelissen JHC, Kattge J, Bönisch G, Römermann C (2017) Advances in flowering phenology across the Northern Hemisphere are explained by functional traits. Glob Ecol Biogeogr 27(3):310-321. https://doi.org/10.1111/geb.12696

28. Knight ME, Martin AP, Bishop S, Osborne JL, Hale RJ, Sanderson RA, Goulson D (2005) An interspecific comparison of foraging range and nest density of four bumblebee (Bombus) species. Mol Ecol 14(6):1811-1820. https://doi.org/10.1111/j.1365-294X.2005.02540.x

29. Knight ME, Osborne JL, Sanderson RA, Hale RJ, Martin AP, Goulson DG (2009) Bumblebee nest density and the scale of available forage in arable landscapes. Insect Conserv Divers 2(2):116-124. https://doi.org/10.1111/j.1752-4598.2009.00049.x

30. Lüdecke D (2018) sjPlot: Data visualization for statistics in social science. R package version 2(1). CRAN https://strengejacke.github.io/sjPlot/ Accessed 19 July 2021

31. MacDougall AS, Beckwith BR, Maslovat CY (2004) Defining conservation strategies with historical perspectives: a case study from a degraded oak grassland ecosystem. Conserv Biol 18(2):455-465. https://doi.org/10.1111/j.1523-1739.2004.00483.x 
32. Madrone Environmental Services Ltd (2008) Terrestrial Ecosystem Mapping of the Coastal Douglas-Fir Biogeoclimatic Zone. (Dossier 07.0359). https://bvcentre.ca/files/research_reports/0717_TEM_4522_rpt_only.pdf Accessed 19 July 2021

33. Martin T, Arcese P, Scheerder N (2011) Browsing down our natural heritage: Deer impacts on vegetation structure and songbird populations across an island archipelago. Biol Conserv 144(1):459-469. https://doi.org/10.1016/j.biocon.2010.09.033

34. Marx HE, Giblin EG, Dunwiddie PW, Tank DC (2016) Deconstructing Darwin's Naturalization Conundrum in the San Juan Islands using community phylogenetics and functional traits. Divers Distrib 22(3):318331. https://doi.org/10.1111/ddi.12401

35. McFrederick QS, LeBuhn G (2006) Are urban parks refuges for bumble bees Bombus spp. (Hymenoptera: Apidae)? Biol. Conserv 129(3):372-382. https://doi.org/10.1016/j.biocon.2005.11.004

36. Minckley RL, Roulston TH, Williams NM (2013) Resource assurance predicts specialist and generalist bee activity in drought. Proc. R. Soc. Lond. 280(1759):1-7. https://doi.org/10.1098/rspb.2012.2703

37. Moore RD, Spittlehouse DL, Whitfield PH, Stahl K (2010) Weather and climate.. In: In: Pike RG, Redding TE, Moore RD, Winkler RD, Bladon KD (eds) Compendium of forest hydrology and geomorphology in British Columbia. Land Management Handbook. Ministry of Forests and Range, Victoria, pp 47-83

38. Morón DP, Skorka P, Lenda M, Rożej-Pabijan E, Wantuch M, Kajzer-Bonk J, Celary W et al (2014) Railway embankments as new habitat for pollinators in an Agricultural Landscape. PLoS ONE 9(7):e101297. https://doi.org/10.1371/journal.pone.0101297

39. Nuszdorfer FC, Klinka K, Demarchi DA (1991) Coastal Douglas-fir zone.. In: In: Meidinger DV, Pojar J (eds) Ecosystems of British Columbia. Ministry of Forests Research Branch, Smithers, pp 81-93

40. Osborne JL, Martin AP, Carreck NL, Swain JL, Knight ME, Goulson D, Hale RJ, Sanderson RA (2008) Bumblebee flight distances in relation to the forage landscape. J Anim Ecol 77(2):406-415. https://doi.org/10.1111/j.1365-2656.2007.01333.x

41. Pérez-Camacho L, Rebollo S, Hernández-Santana V, García-Salgado G, Pavón-García J, Gómez-Sal A (2012) Plant functional trait responses to interannual rainfall variability, summer drought and seasonal grazing in Mediterranean herbaceous communities. Funct Ecol 26(3):740-749. https://doi.org/10.1111/j.1365-2435.2012.01967.x

42. Phillips BB, Shaw RF, Holland MJ, Fry EL, Bardgett RD, Bullock JM, Osborne JL (2018) Drought reduces floral resources for pollinators. Glob Change Biol 24(7):3226-3235. https://doi.org/10.1111/gcb.14130

43. Pinheiro J, Bates D, DebRoy S, Sarkar D, R Core Team (2021) nlme: Linear and nonlinear mixed effects models. R package version 3:1-140

44. Potts SG, Vulliamy B, Roberts S, O'Toole C, Dafni A, Ne'eman G, Willmer P (2005) Role of nesting resources in organising diverse bee communities in a Mediterranean landscape. Ecol Entomol 30(1):7885. https://doi.org/10.1111/j.0307-6946.2005.00662.x

45. R Core Team (2019) R: A language and environment for statistical computing. R Foundation for Statistical Computing, Vienna, Austria

46. Rao S, Strange JP (2012) Bumble bee (Hymenoptera: Apidae) foraging distance and colony density associated with a late-season mass flowering crop. Environ Entomol 41(4):905-915. 
https://doi.org/10.1603/EN11316

47. Rogan JE, Lacher TE Jr (2018) Impacts of habitat loss and fragmentation on terrestrial biodiversity. Reference Module in Earth Systems and Environmental Sciences, Elsevier. https://doi.org/10.1016/b9780-12-409548-9.10913-3

48. Rundlöf M, Persson AS, Smith HG, Bommarco R (2014) Late-season mass-flowering red clover increases bumble bee queen and male densities Biol. Conserv 172:138-145.

https://doi.org/10.1016/j.biocon.2014.02.027

49. Salathé EP, Steed R, Mass CF, Zahn PH (2008) A high-resolution climate model for the United States Pacific Northwest: mesoscale feed-backs and local responses to climate change. J Clim 21(21):57085726. https://doi.org/10.1175/2008JCLI2090.1

50. Sanchez-Bayo F, Goka K (2014) Pesticide residues and bees - A risk assessment. PLoS ONE 9(4):e94482. https://doi.org/10.1371/journal.pone.0094482

51. Seager R, Osborn TJ, Kushnir Y, Simpson IR, Nakamura J, Liu H (2019) Climate variability and change of Mediterranean-type climates. J Clim 32(10):2887-2915. https://doi.org/10.1175/JCLI-D-18-0472.1

52. Shackelford N, Murray SM, Bennett JR, Lilley PL, Starzomski BM, Standish RJ (2019) Ten years of pulling: Ecosystem recovery after long-term weed management in Garry oak savanna. Conserv Sci Prac 1(10):e92. https://doi.org/10.1111/csp2.92

53. Shackelford N, Standish RJ, Ripple W, Starzomski BM (2018) Threats to biodiversity from cumulative human impacts in one of North America's last wildlife frontiers. Conserv Biol 32(3):672-684. https://doi.org/10.1111/cobi.13036

54. Simon ADF, Marx HE, Starzomski BM (2021) Phylogenetic restriction of plant invasion in droughtstressed environments: implications for insect-pollinated plant communities in water-limited ecosystems. Ecol Evol 00:1-12. https://doi.org/10.1002/ece3.7776

55. Soroye P, Newbold T, Kerr J (2020) Climate change contributes to widespread declines among bumble bees across continents. Science 367(6478):685-688. https://doi.org/10.1126/science.aax8591

56. Spies TA, Giesen TW, Swanson FJ, Franklin JF, Lach D, Johnson KN (2010) Climate change adaptation strategies for federal forests of the Pacific Northwest, U.S.A.: ecological, policy, and socioeconomic perspectives. Landsc Ecol 25(8):1185-1199. https://doi.org/10.1007/s10980-010-9483-0

57. Straka JR, Starzomski BM (2014) Humming along or buzzing off? The elusive consequences of plantpollinator mismatches. J Pollinat Ecol 13(14):129-145. https://doi.org/10.26786/1920-7603(2014)18

58. Stephen WP, Rao S (2005) Unscented traps for non-Apis bees (Hymenoptera: Apoidea). J Kans Entomol Soc 78:373-380. https://doi.org/10.2317/0410.03.1

59. Szabo ND, Colla SR, Wagner DL, Gall LF, Kerr JT (2012) Do pathogen spillover, pesticide use, or habitat loss explain recent North American bumblebee declines? Conserv Lett 5(3):232-239. https://doi.org/10.1111/j.1755-263X.2012.00234.x

60. Thomson DM (2016) Local bumble bee decline linked to recovery of honey bees, drought effects on floral resources. Ecol Lett 19(10):1247-1255. https://doi.org/10.1111/ele.12659

61. van Dam-Bates P, Gansell O, Robertson B (2018) Using balanced acceptance sampling as a master sample for environmental surveys. Methods Ecol Evol 9(7):1718-1726. https://doi. org/10.1111/2041- 
210X.. 13003

62. Venables WN, Ripley BD (2002) Modern Applied Statistics with S. Fourth Edition. Springer, New York, NY

63. Vickruck JL, Best LR, Gavin MP, Devries JH, Galpern P (2019) Pothole wetlands provide reservoir habitat for native bees in prairie croplands. Biol Conserv 232:43-50.

https://doi.org/10.1016/j.biocon.2019.01.015

64. Williams NM, Regetz J, Kremen C (2012) Landscape-scale resources promote colony growth but not reproductive performance of bumble bees. Ecology 93(5):1049-1058. https://doi.org/10.1890/111006.1

65. Williams PH, Thorp RW, Richardson LL, Colla SR (2014) Bumble bees of North America: an identification guide. Princeton University Press, Princeton, NJ

66. Wray JC, Elle E (2015) Flowering phenology and nesting resources influence pollinator community composition in a fragmented ecosystem. Landsc Ecol 30(2):261-272. https://doi.org/10.1007/s10980014-0121-0

67. Statements, Declarations

68. This research was funded by the BC Parks Living Labs (Ministry of Environment and Climate Change Strategy Agreement \# TP19JHQ014) and the Natural Sciences and Engineering Research Council of Canada (RGPIN 2017 04476).

69. The authors have no relevant financial or non-financial interests to disclose

\section{Figures}




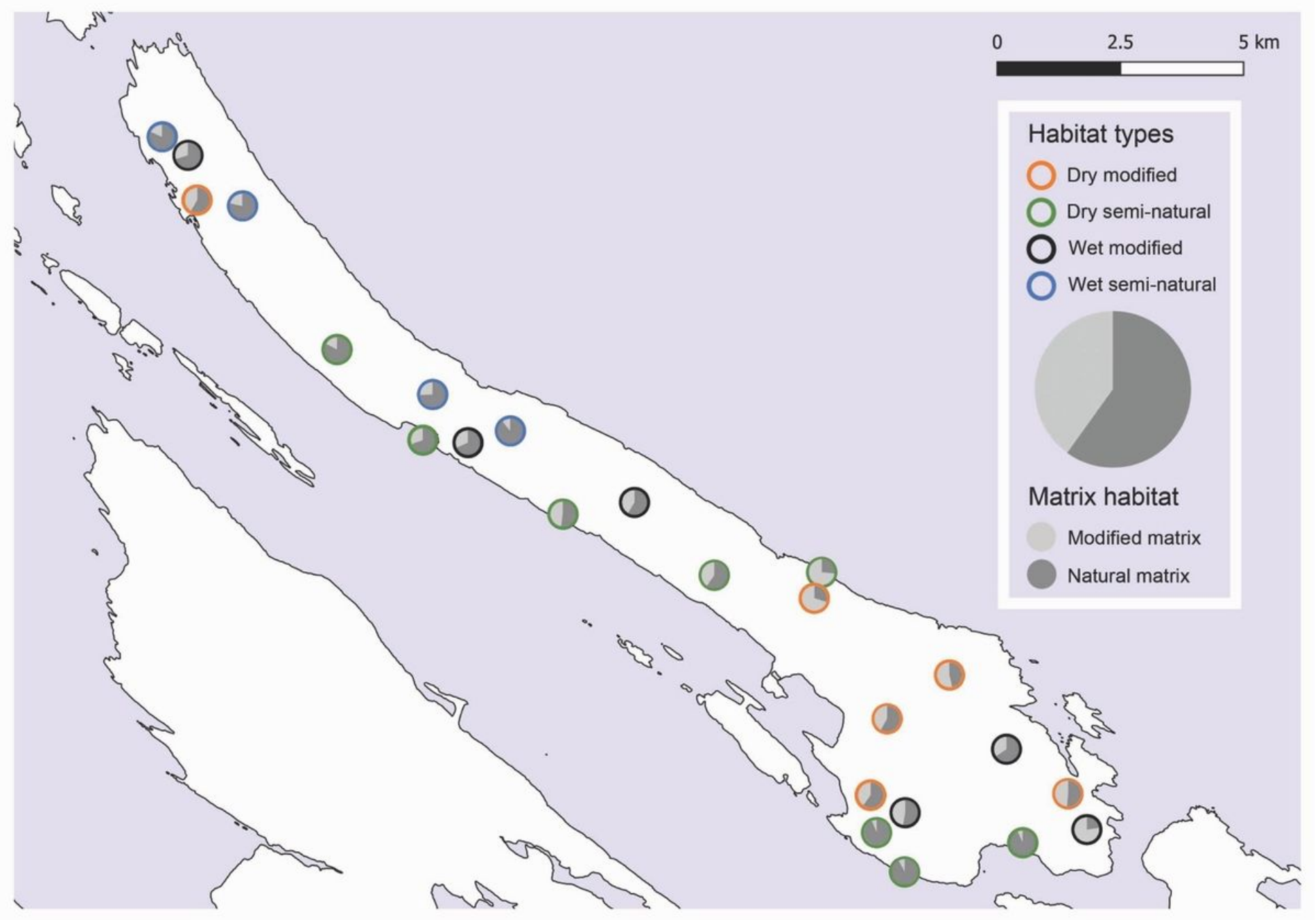

\section{Figure 1}

Site locations on Galiano Island, BC, by habitat type and proportion of surrounding natural versus modified matrix habitat 


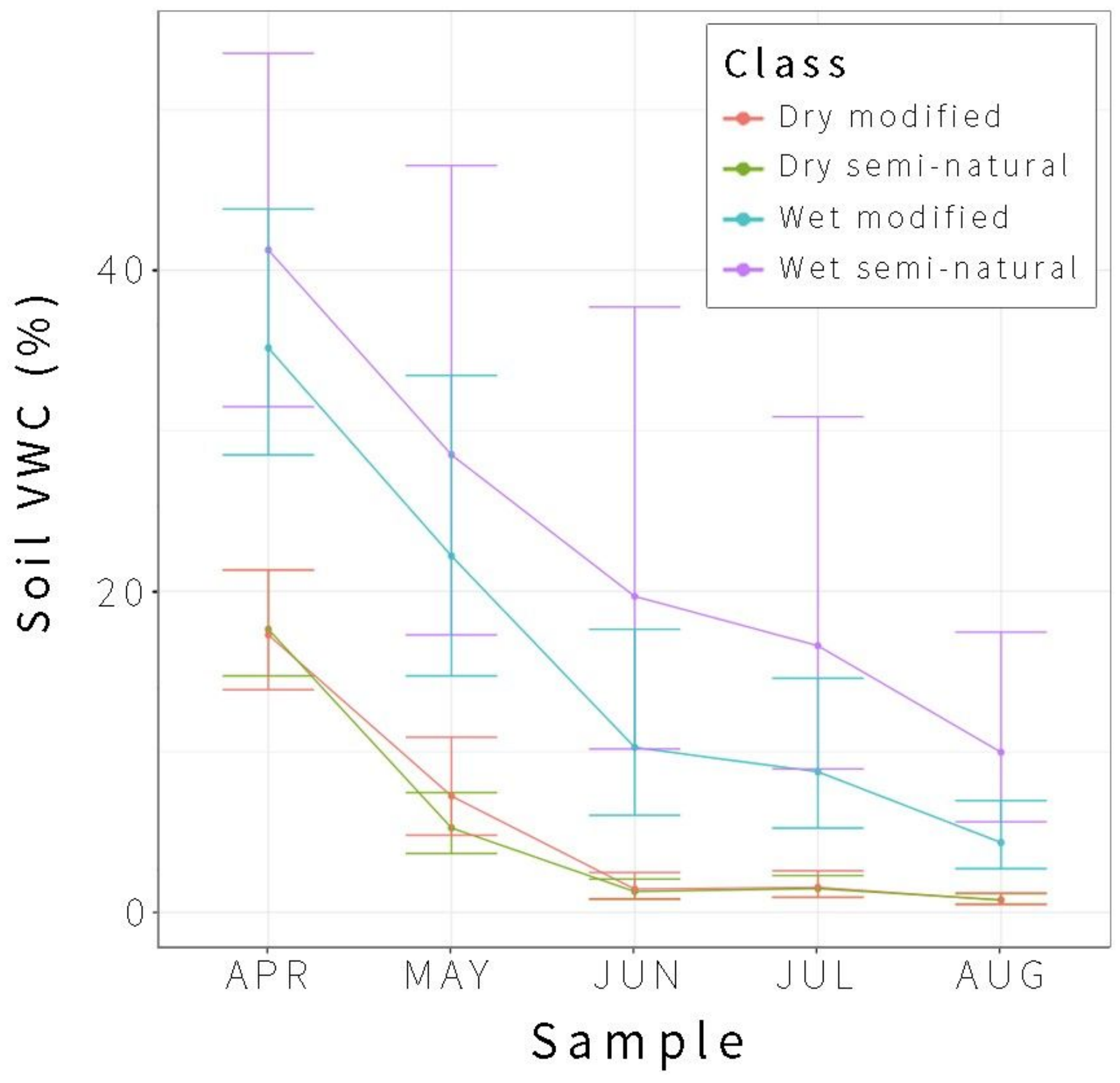

Figure 2

Mean soil moisture across each site class from April through August, shown with $95 \%$ confidence intervals (LMM estimates). Soil moisture was estimated as volumetric water content (\%VWC), a ratio of water to soil $(\mathrm{m} 3 / \mathrm{m} 3)$, using a TDR probe. All differences in wet versus dry site conditions are significant at $\mathrm{p}=$ $<.001-.001$ 


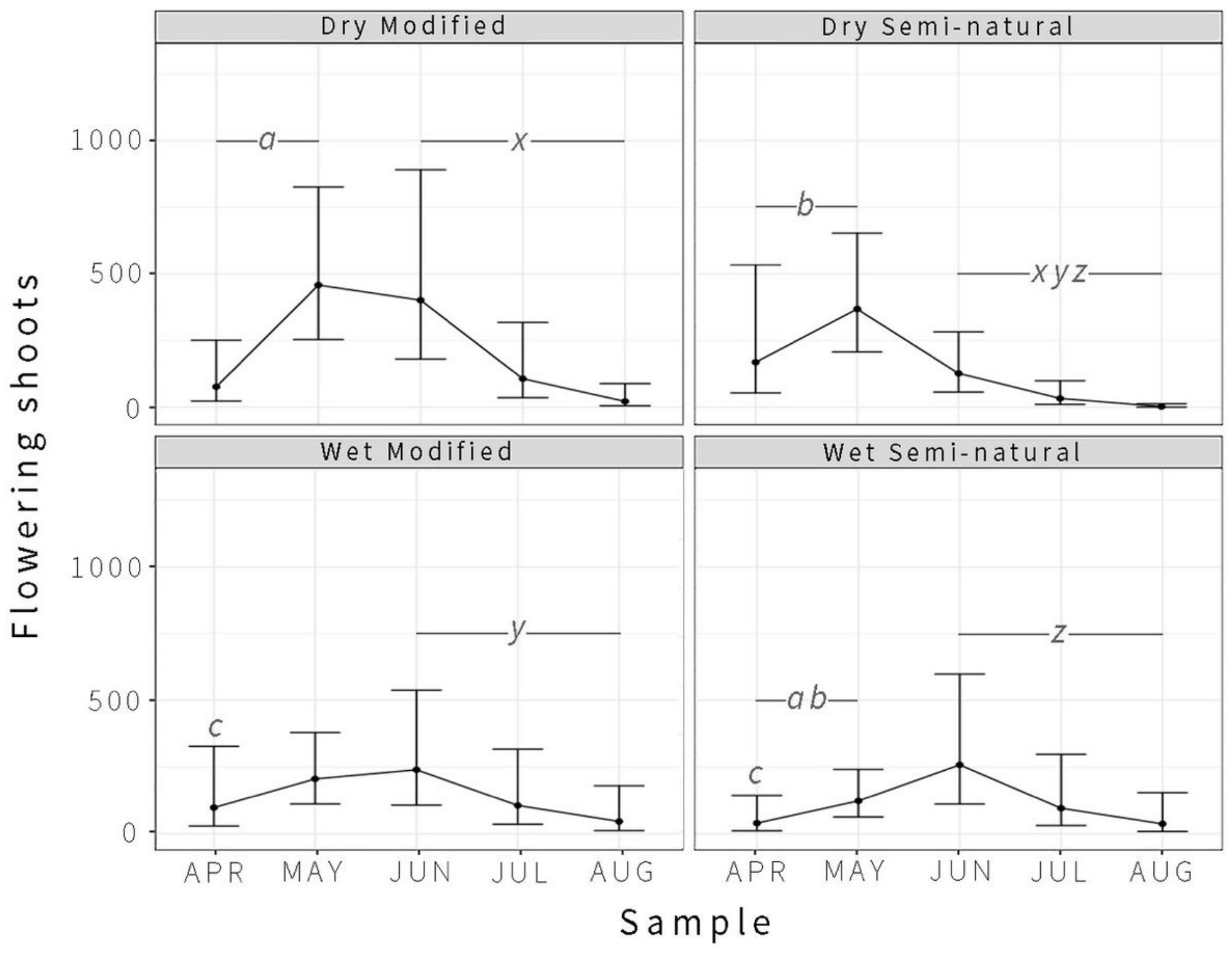

\section{Figure 3}

Model outputs of counts of flowering shoots across habitats and samples, with $95 \%$ confidence intervals. Significant differences between site conditions, both for independent samples and across sample ranges, are marked with letters ( $a$ is significantly different from $b, x$ significantly different than $y$ ). All differences significant at $p=<.001-.02$ 


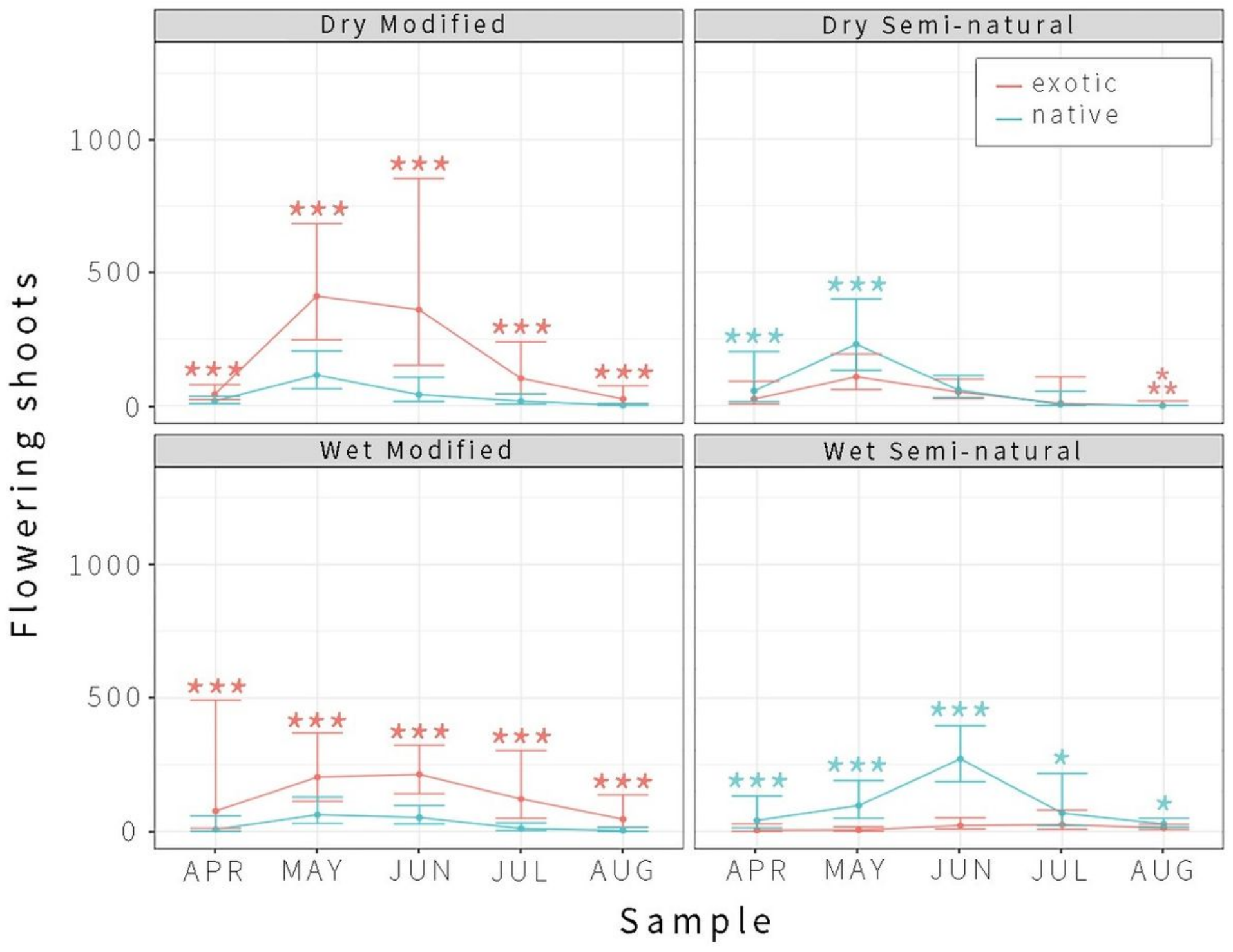

Figure 4

Mean Floral Resource Availability (FRA) among native versus exotic plants across habitats and samples, with $95 \%$ confidence intervals (GLMM estimates). Asterisks indicate significant differences between native versus

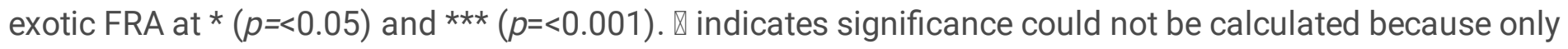
exotic species are present 


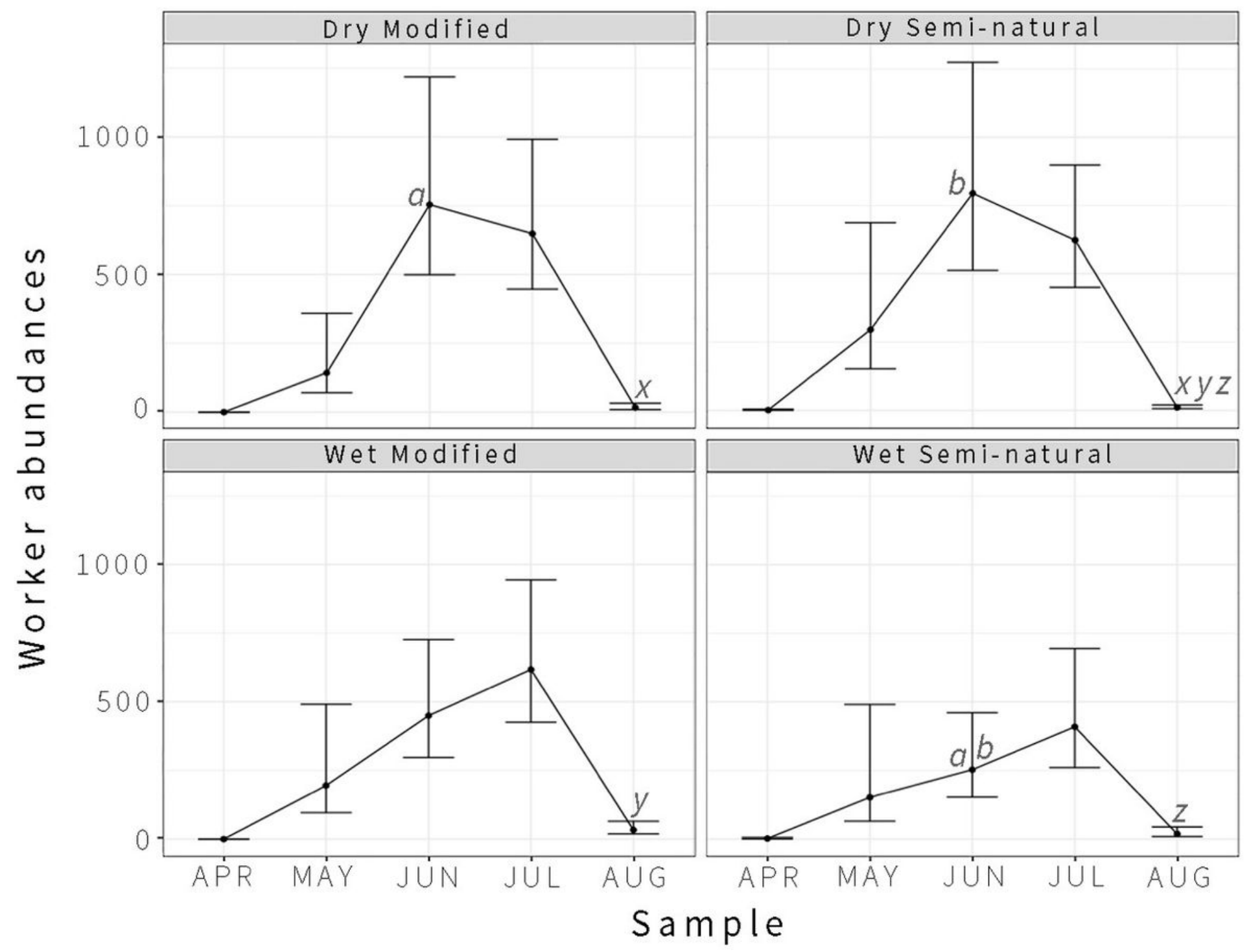

Figure 5

Mean bumble bee worker abundance across habitats and samples, with 95\% confidence intervals (GLM estimates). Significant differences between site conditions are marked with letters (a is significantly different from $a, b$ significantly different from $b$...). All differences significant at $p=<0.01$ 


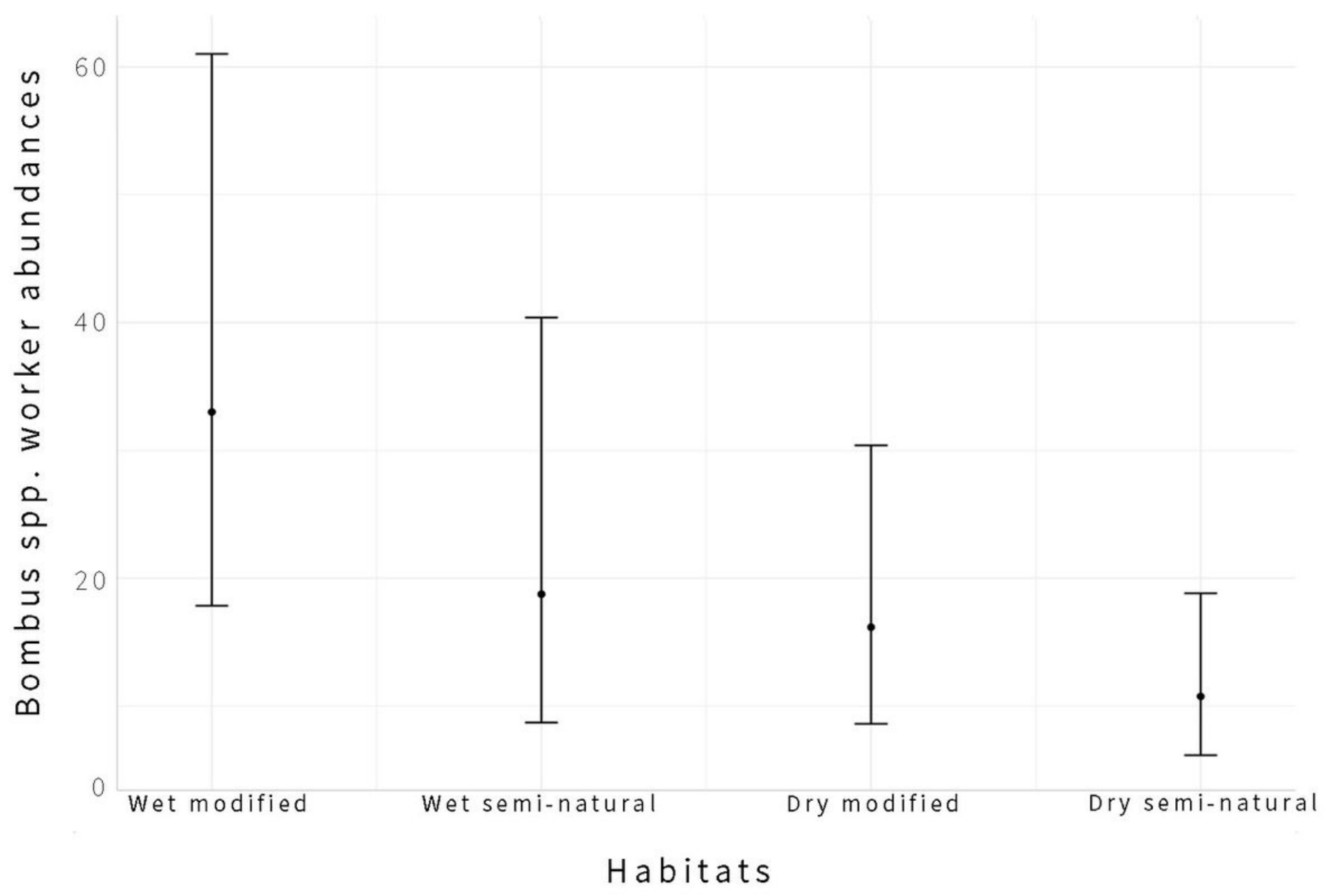

Figure 6

Mean worker abundance across habitat types in August, with 95\% confidence intervals

\section{Supplementary Files}

This is a list of supplementary files associated with this preprint. Click to download.

- SupplementaryInformation20211121.docx 